Remy Attig (2012): Did the Sephardic Jews Speak Ladino?, Bulletin of Spanish Studies: Hispanic Studies and Researches on Spain, Portugal and Latin America, 89:6, 831-838

\title{
Did the Sephardic Jews Speak Ladino?
}

\author{
REMY ATTIG \\ University of Ottawa
}

In 1492 the Jews of Spain were presented with a choice, convert to Christianity or leave the country. Many Jews stayed in Spain and either converted or went into hiding; many more reluctantly chose to leave. A large percentage of exiled Spanish Jews (known as Sephardim) settled in the Ottoman Empire. For them the Spanish cultural and linguistic heritage remained alive for centuries after the expulsion. Even today a Spanish-based language can be heard among the older generation of the Turkish Jewish community. According to the online dictionary of the Real Academia Española (hereafter DRAE) this language is known as 'Ladino', but is that the correct name? Two of the eight definitions for the term 'Ladino' in the DRAE refer to the language of the Sephardic Jews:

7. m. Ling. Lengua religiosa de los sefardíes. Es calco de la sintaxis y del vocabulario de los textos bíblicos hebreos y se escribe con letras latinas o con caracteres rasíes.8. m. Ling. Variedad del castellano que, en época medieval, hablaban los judíos en España, y que, en la actualidad, hablan los judeoespañoles en Oriente.

Some Jewish Studies scholars might find these two definitions in DRAE misleading, especially if the term is placed in a proper historical context.

Following anti-Semitic uprisings in the fourteenth century, the Jewish community of Spain began an exodus from the Iberian Peninsula that reached its climax following the edict of 
expulsion of $1492 .{ }^{1}$ While living in Spain, the Sephardim spoke a variety of Iberian languages;

after their departure, they continued to speak these languages in exile. Although large communities of Sephardim were established in North Africa (notably Morocco), the focus of this article is on the evolution and proper name of the language spoken by those who settled in the Ottoman Empire. ${ }^{2}$ Upon their arrival in Ottoman lands, the Sephardim founded communities and attended synagogues according to the language that they spoke, be it Castilian, Aragonese, Catalan, Galician, Portuguese or other Iberian languages. ${ }^{3}$ Over time these groups of varying linguistic backgrounds created a common language that was understood by the entirety of the Sephardic community, though regional dialects still persisted. ${ }^{4}$ This new language continued to evolve, thus further setting itself apart from the original Iberian languages, particularly Castilian. Since the Sephardim did not adopt many of the phonetic changes that affected Castilian during the sixteenth and especially the seventeenth century, their speech now sounded antiquated when compared to modern Castilian.

Literary production in this new Sephardic language flourished with the publication of religious texts in the eighteenth century. ${ }^{5}$ The nineteenth and early twentieth centuries saw the

\footnotetext{
${ }^{1}$ Jane S. Gerber, The Jews of Spain : a history of the Sephardic experience (New York: Free Press, 1992), 113-14. And Howard M. Sachar, Farewell España : The World of the Sephardim Remembered (New York: Vintage Books, 1994), 71-73.

${ }^{2}$ For more information about Judeo-Arabic, a language used by some Sephardim, consult: Norman A. Stillman 'The Judeo-Arabic Heritage', Sephardic \& Mizrahi Jewry: From the Golden Age of Spain to Modern Times ed. Zion Zohar (New York: New York University Press, 2005), 40-54

${ }^{3}$ Gerber, 154. For more information on the use of the Basque language among medieval Jews consult: David L. Gold, 'We Do Not Know Whether Jews in Sefarad Spoke or Wrote Basque', Fontes Linguae Vasconum; Studia et Documenta, 35/94: (2003), 537-40.

${ }^{4}$ M. L. Wagner, 'Algunas observaciones generales sobre el judeo-español de Oriente', Revista de filología española, 10/3: (1923), 225-44 (p. 233-34).

${ }_{5}^{5}$ Sachar, 95. For further reading on the literature of the Sephardim consult: Cecil Roth, $A$ History of the Marranos (Philadelphia: The Jewish Publication Society of America, 1932), 32238.
}

Remy Attig (2012): Did the Sephardic Jews Speak Ladino?, Bulletin of Spanish Studies: Hispanic Studies and Researches on Spain, Portugal and Latin America, 89:6, 831-838 
emergence of plays, novels and newspapers, first printed in a variation of the Hebrew alphabet, and only very much later with Latin characters. World War II marked a substantial decline in Sephardic literary production due to the near-total annihilation of this community in the former Ottoman lands. Only in Turkey and Israel, as a result of later immigration, does this language survive. ${ }^{6}$

There has been much debate among scholars of Jewish Studies as to the proper name for this language. Some have suggested the following terms, each intending to focus on a different variety, dialect or register of the language: Judezmo, Ladino, Spanyolit, Judeo-Spanish, Djidio, and Kasteyano Muestro. But even native speakers of this language cannot decide what is the proper denomination. ${ }^{7}$ This is evidenced in a recent debate that took place on Ladinokomunita, the list-serve geared towards speakers of this language (employing the term 'Ladino' in the name itself). José Poveda, for example, argues that the spoken language should be called JudeoEspanyol (or Judeo-Spanish), while the term 'Ladino' should be reserved for calque translations. ${ }^{8}$ For her part, Gloria Ascher, agrees that Ladino is not the right name for this language; she suggests the terms 'Spanyol' or 'Spanyol de mozotros' to refer to her native tongue. ${ }^{9}$ When asked about the confusion surrounding this issue, Moshe Shaul, editor of the Sephardic periodical Aki Yerushalayim, replied: 'It does not matter to me what name is used for

\footnotetext{
${ }^{6}$ Note that dialects of this language survive as post-vernacular languages (languages of nostalgia) in many Sephardic communities in the Americas and in Morocco where it is heard in songs and idiomatic expressions. Only in Turkey and Israel are there sizeable communities of native speakers who use Judeo-Spanish for daily communication.

${ }^{7}$ Whether we should give preference to the names preferred by native speakers is up for debate, as indicated by David Gold; he suggests that even current native speakers may not be informed enough of their language to serve as an authority regarding original terminology and usage. David L. Gold, 'Planning Glottonyms for Jewish Languages (With Emphasis on Judezmo and Yahudic)', Jewish Language Review, 3: (1983), 71-95 (p. 71). ${ }^{8}$ José Poveda, 'El ladino i el djud[e]o-espanyol ', in Ladinokomunita, (Gran Canaria, 2011). ${ }^{9}$ Gloria J. Ascher, 'Teaching "Ladino Language and Culture" and "Aspects of the Sephardic Tradition": Hopes, Fruits, Experiences', Shofar, 19/4: (2001), 77-84 (p. 78).
}

Remy Attig (2012): Did the Sephardic Jews Speak Ladino?, Bulletin of Spanish Studies: Hispanic Studies and Researches on Spain, Portugal and Latin America, 89:6, 831-838 
our language. What matters is that people speak it, read it and try to write letters, poetry, articles and books in this language - as only in this way will it be able to keep on living'. ${ }^{10}$ Though it may not matter to its speakers, it seems to me that the vernacular language of the Sephardic Jews still living in the lands of the former Ottoman Empire needs to be given a name that we can all agree upon. Most Hispanists would perhaps argue that the term 'Ladino', as defined by the DRAE, is the correct term for this language. However there are several objections one may raise to entries 7 and 8 of the present definition.

7. m. Ling. Lengua religiosa de los sefardíes. Es calco de la sintaxis y del vocabulario de los textos bíblicos hebreos y se escribe con letras latinas o con caracteres rasíes.

This definition implies that Ladino effectively replaced Hebrew as the liturgical language of the Sephardic Jews. Hebrew is, and always has been, the liturgical and religious language of all the Sephardim. However, since the entirety of the Sephardic population was not able to read and understand Hebrew, rabbis explained ethics and proper conduct through a didactic literature known as musar. In the past, musar literature was written in Hebrew. But, due to the low rate of Hebrew-language literacy among the Sephardic communities (particularly among Jews who left Spain after 1600 and joined their coreligionists in the Ottoman Empire), rabbis made musar as well as biblical texts available to the population at large by preparing calque translations of the Hebrew originals. ${ }^{11}$ The term 'Ladino', originally used as a designator for these calque

\footnotetext{
${ }^{10}$ Alla Markova, Beginner's Ladino : with 2 audio CDs (Hippocrene beginner's series; New York: Hippocrene Books, 2008), 1.

${ }^{11}$ David M. Bunis, 'The Language of the Sephardim: A Historical Overview', in Haim Beinart (ed.), Moreshet Sepharad: The Sephardi Legacy vol. 2 (Jerusalem: The Hebrew University Magnes Press, 1992), 407.

Remy Attig (2012): Did the Sephardic Jews Speak Ladino?, Bulletin of Spanish Studies: Hispanic Studies and Researches on Spain, Portugal and Latin America, 89:6, 831-838
} 
translations, was later given a verb form, 'enladinar', which means to render a Hebrew or Aramaic text into a Romance vernacular. The two earliest works written in this language were Jacob Huli's Meam Loez (first instalment in 1730) and Abraham Asa's translation of the Bible (1739). ${ }^{12}$ The DRAE is accurate in its description of the calque nature of these translations. Those translators did not produce a text written in the native vernacular of the readers; their translations followed Hebrew syntax while replacing the Hebrew words with Iberian ones. Although they were translations, these texts also included large chunks of the Hebrew original that the rabbis and translators presumed the reading public could understand. ${ }^{13}$ Sometimes, the translators would provide more, and at other times less, commentary in the translations than in the original, prompting some scholars to refer to these texts not as translations but as adaptations. Scholars don't always agree about the degree to which a document must be a word-for-word translation rather than an adaptation to be considered a 'Ladino' text. Haim Vidal Sephiha, for example, provides a very narrow definition of the language. He suggests that the term should be applied to the language used for biblical translations but not for musar. ${ }^{14}$ On the other hand, Matthias B. Lehmann argues for a broader definition. ${ }^{15}$ He explains that written Ladino was not intended to be read by individuals but rather in a group setting known as a meldado. This group setting served as a forum for the community to work together to understand these texts, making religious learning accessible to all. ${ }^{16}$ Despite some minor discrepancies, the general consensus

\footnotetext{
${ }^{12}$ Matthias B. Lehmann, Ladino Rabbinic Literature \& Ottoman Sephardic Culture (Bloomington, IN: Indiana University Press, 2005), 34.

${ }^{13}$ Lehmann, 55

${ }^{14}$ Haïm Vidal Sephiha, 'Le ladino : de l'hébrue habillé d'espagnol ou le paradis calqué', Faits de langues, 18 (2001), 191-200 (p. 193).

${ }^{15}$ Lehmann, 52.

${ }^{16}$ Lehmann, 78. It is important to note that though some rabbis working in Ladino apologised for using Ladino and justified it as directed to females who did not know Hebrew, Lehmann suggests that the shift of rabbis away from producing didactic literature in Hebrew was due to
} 
among Jewish Studies scholars is that Ladino became the 'religious' language of the exiled Sephardic community only in reference to the translations and the musar literature that served to make the Hebrew or Aramaic texts accessible to those who could not read the original. It did not replace Hebrew as the religious or liturgical language of the Sephardim, as the DRAE definition implies.

8. m. Ling. Variedad del castellano que, en época medieval, hablaban los judios en España, y que, en la actualidad, hablan los judeoespañoles en Oriente.

This definition of Ladino states that it was the medieval language of the Jews of Spain and is the current language of the Sephardim in the East. In the first place, Ladino, as a language, did not exist in the Middle Ages. As indicated above, Ladino is a written language that developed only in the early eighteenth century and in all likelihood never had a spoken tradition. ${ }^{17}$ Prior to their exile, the Jews of Medieval Spain, like the Jews in modern-day North America, were a highly integrated community. They spoke Castilian, Catalan, Galician, or other languages (with an infusion of Hebrew and Arabic loanwords) based on the region in which they lived. In this regard Spanish Jews were very different from their contemporary Yiddish-speaking coreligionists in Eastern Europe who spoke a uniquely Jewish language. ${ }^{18}$ David Bunis says:

their dissatisfaction with the overall educational standards of the time among both men and women. See Lehmann, 35-39.

${ }^{17}$ Paul Wexler, 'Ascertaining the position of Judezmo within Ibero-Romance', Vox romanica, 36 : (1977), 162-95 (p. 163).

${ }^{18}$ A brief history of the conditions and development of Yiddish can be found in: Paul Kriwaczek, Yiddish Civilization: The Rise and Fall of a Forgotten Nation. (New York, Alfred A. Knopf, 2005), 96-97.

Remy Attig (2012): Did the Sephardic Jews Speak Ladino?, Bulletin of Spanish Studies: Hispanic Studies and Researches on Spain, Portugal and Latin America, 89:6, 831-838 
Native texts replicating the popular spoken language of the medieval Sephardim do not exist, but if we may judge by the Hispanic elements preserved in the modern popular vernacular, most of the Hispanic elements employed on an everyday basis by the average medieval Sephardi may have differed little, if at all, from the popular forms used by their average Christian neighbours - from whom they probably learned them in the first place through direct interaction in the marketplace and local neighborhoods. ${ }^{19}$

These varieties of Iberian languages differed from the speech of the predominantly Christian population much in the same way that modern Jewish English dialects deviate, at times only slightly, from Standard English. ${ }^{20}$

The eighth DRAE definition also ignores the possibility of any substantial linguistic evolution in the language spoken by the Sephardim between the Middle Ages and the present day. Ramón Menéndez Pidal and Ángel Pulido were among the philologists who provided the basis for Royce W. Miller's view that:

If we look closely at the language of this [Sephardic] folk literature, we are rewarded linguistically with a living monument of Old Spanish. Words, linguistic processes, grammatical and syntactical structures antedating 1492 are all there for the linguist to explore, as though time had stood still. Living, breathing people speak the language kept for us from a moment in the past. ${ }^{21}$

But time, of course, did not stand still any more for the Sephardim than it did for Castilians.

David Bunis points out that the 'break with Iberian Castilian enabled the language of the Jews to develop more independently of Castilian influence than it had in Spain. The internal tendencies

\footnotetext{
${ }^{19}$ Bunis, 'The Language of the Sephardim: A Historical Overview', 403.

${ }^{20}$ For more information on what constitutes Jewish English consult: David L. Gold, 'An Introduction to Jewish English', Jewish Language Review, 6: (1986), 94-120. More information regarding the difference between the medieval Ibero-Romance languages of the Jews and Christians can be found in: Bunis, 'The Language of the Sephardim: A Historical Overview', 402-04. and Aron Rodrigue, 'The Ottoman Diaspora: The Rise and Fall of Ladino Literary Culture', in David Biale (ed.), Cultures of the Jews: A New History (New York: Schocken Books, 2002), 863-85.

${ }^{21}$ Royce W. Miller, 'The Sephardim and Their Folk Literature', Revue des études juives, 152: (1993), 193-99 (p. 193).
}

Remy Attig (2012): Did the Sephardic Jews Speak Ladino?, Bulletin of Spanish Studies: Hispanic Studies and Researches on Spain, Portugal and Latin America, 89:6, 831-838 
and trends of its speakers took their natural course without pressure from the host community'. ${ }^{22}$ This allowed the Sephardim to remain at times more conservative than the Iberians in their usage of the language and at times adopt new forms more readily. Bunis describes three main periods in the evolution of the language; old, middle and modern. ${ }^{23}$ In fact, as pointed out above, even the idea that the Sephardic Jews were originally part of any linguistically homogenous group is erroneous. The Jews expelled in 1492 took with them into exile the languages and dialects spoken in the regions where they had lived: Castile, Aragon, Catalonia, Balearic Islands, etc. The expulsion of the Jews from Portugal in 1497 pushed much of the Lusophone Jewish community into exile and some of them joined their coreligionists from Castile and Aragon in the Ottoman Empire, thus adding Portuguese to the list of languages spoken by the Jewish immigrants there. Jane S. Gerber explains that the language of the Ottoman Sephardim is the result of a fusion of these original Iberian languages with borrowings from Hebrew, Aramaic, Greek, Turkish and some local dialects. ${ }^{24}$ Paul Wexler describes and diagrams two differing views on the origin of the Sephardic vernacular. While some of Wexler's research has been questioned by prominent scholars in the field of Jewish languages, he usefully outlines the mainstream view of the evolution of this Sephardic vernacular that was in essence based on Castilian with substantial influences from Catalan and Portuguese. ${ }^{25}$ As Mahir Saul explains, prior to its substantial decline following World War II there were in all likelihood more than one dialect of this language. He identifies two dialects among the Sephardim living in Turkey and

${ }^{22}$ David M. Bunis, 'Judeo-Spanish Culture in Medieval and Modern Times ', in Zion Zohar (ed.), Sephardic \& Mizrahi Jewry: From the Golden Age of Spain to Modern Times (New York: New York University Press, 2005), 55-76 (p. 58).

${ }^{23}$ Bunis, 'The Language of the Sephardim: A Historical Overview', 402.

24 Gerber, 156.

${ }^{25}$ Wexler, Paul, 'Ascertaining the position of Judezmo within Ibero-Romance', Vox romanica, 36 (1977) 162-95.

Remy Attig (2012): Did the Sephardic Jews Speak Ladino?, Bulletin of Spanish Studies: Hispanic Studies and Researches on Spain, Portugal and Latin America, 89:6, 831-838 
the Balkans. The first dialect spoken in present-day Turkey is similar to Castilian. The second dialect, spoken in the Sephardic communities of Bosnia, Romania, Macedonia, and Salonika (Thessaloniki), 'contains features reminiscent of characteristics of northern Spanish dialects and Portuguese'. ${ }^{26}$ In other words, not only is this language different from the various languages spoken by the Jews in medieval Spain, it has evolved substantially in the last five centuries, though in different ways from Castilian.

Furthermore, a search of the word 'Ladino' in the Corpus diacrónico del español (CORDE), the Real Academia Española's searchable database of historic Spanish texts, shows that the term did not refer to a specifically Jewish language, but rather to the ability of a nonChristian Spaniard (a category that would include Jews and Moors) to speak Latin or Castilian fluently. Examples of this usage can be seen in the following quotes:

E maguer los que fazen tal pleyto no fablasen amos vn lenguaie como si el vno fablasse ladino \& el otro arauigo vale la promission solamente que se entienda el vno al otro sobre la pregunta $\&$ respuesta. Eso mismo dezimos que seria si fuessen amos de dos lenguaies maguer no lo entendiese el vno al otro. - Siete partidas de Alfonso X (1491 edition).

Y el otro tercio de África comiença de Alexandría con una partida de la provincia de Egipto y tiene desde al cibdad de Barta, que es en la parte de Oriente, fasta Tangad Aladia, que es a la parte de Poniente y dízenle en ladino Mauritana. Y tiene en ancho desde la mar fasta los arenales que se tienen con las tierras de los etíopes; y son grandes arenales \& grandes sierras y van desde Poniente fasta en Oriente. - Libro del cavallero Cifar $(1300-1305){ }^{27}$

\footnotetext{
${ }^{26}$ Mahir Saul, 'The Mother Tongue of the Polyglot: Cosmopolitism and Nationalism among the Sephardim of Istanbul', Anthropological Linguistics, 25 3: (1983) 326-58 (p. 327).

${ }^{27}$ Real Academia Española, in Real Academia Española (ed.), Banco de datos (CORDE) [en línea]. Corpus diacrónico del español (Madrid: Real Academia Española, 2011).
} 
In the Tesoro de la lengua castellana o española (1611) Covarrubias' definition of 'Ladino' is as follows:

LADINO. En rigor vale lo mesmo que latino, mudada la $t$ tenue en la $d$ media. La gente bárbara en España deprendió mal la pureza de la lengua romana y a los que la trabajaban y eran elegantes en ella los llamaron ladinos. Estos eran tenidos por discretos y hombres de mucha razón y cuenta, de donde resultó dar este nombre a los que son diestros y solertes en cualquier negocio: al morisco y al extranjero que aprendió nuestra lengua con tanto cuidado que apenas le diferenciamos de nosotros, también le llamamos ladino. ${ }^{28}$

It seems evident that the term 'Ladino' was not used in the Middle Ages to refer to any unique dialects of the Jews of Spain. In modern Spanish this acceptation has been retained in the expression 'saber latín', a phrase used to indicate that someone is considered to be well educated. In this sense, it was possible for a Jew (or anyone else) to speak 'Ladino', but the term clearly did not refer to a separate language that was exclusive to the Jews.

In short, the Sephardic Jews never had a spoken language named Ladino, although, after 1492, they did develop a written language that was known by that name. What then should we call the colloquial language used for centuries by the descendants of the Spanish Jews? Many Jewish scholars and speakers of the language prefer the term 'Judeo-Spanish' or 'judeoespañol' as defined by the DRAE:

1. adj. Perteneciente o relativo a las comunidades sefardíes y a la variedad de lengua española que hablan.

${ }^{28}$ Sebastián de Covarrubias Orozco, Tesoro de la lengua castellana o española, ed. Ignacio Arellano and Rafael Zafra, (Madrid: Iberoamericana, 2006), 1158. 
2. adj. Se dice de la variedad de la lengua española hablada por los sefardíes, principalmente en Asia Menor, los Balcanes y el norte de África. Conserva muchos rasgos del castellano anterior al siglo XVI. U.t.c.s. ${ }^{29}$

As I hope to have shown, the eighth definition of the DRAE is inaccurate and should be removed. The seventh, on the other hand, should, in my opinion, be amended in the following way:

7. m. Ling. Lengua de las traducciones y adaptaciones de los textos religiosos de los sefardies. Es calco de la sintaxis y del vocabulario de los textos bíblicos hebreos y se escribe con letras latinas o con caracteres rasies.

${ }^{29}$ Real Academia Española, Diccionario de la lengua española (Madrid: Real Academia Española, 2001).

Remy Attig (2012): Did the Sephardic Jews Speak Ladino?, Bulletin of Spanish Studies: Hispanic Studies and Researches on Spain, Portugal and Latin America, 89:6, 831-838 